\title{
A Plurilateral Agenda for Services? Assessing the case for a Trade in Services Agreement (TISA)
}

\section{Pierre Sauvé*}

\section{Abstract}

This paper explores a number of procedural and substantive considerations arising from ongoing attempts to craft a plurilateral Trade in Services Agreement (TISA) among the so-called "Really Good Friends of Services" coalition of WTO Members. The paper suggests that considerable scope exists to move forward a multilateral negotiating agenda on services that both the digital revolution and a continued surge of preferential rule-making has rendered increasingly obsolete. As the most significant attempt to date to craft a GATS Article V-compatible PTA in services, TISA offers considerable promise. The paper, however, cautions that the case for embedding TISA into the architecture of WTO rules alongside the General Agreement on Trade in Services or in its place is weak on both procedural and substantive grounds to the extent that the ongoing talks take place behind doors that remain closed even to the WTO Secretariat, let alone to many of the world's leading developing country suppliers of services, and involve potentially significant departures from GATS rules liable to complicate any hoped for multilateral migratory journey.

Key words: WTO, GATS, trade in services, plurilateral agreements, critical mass negotiations, preferential trade liberalization.

Research for this paper was funded by the Swiss National Science Foundation under a grant to the National Centre of Competence in Research on Trade Regulation, based at the World Trade Institute of the University of Bern, Switzerland.

*Director of External Programs and Academic Partnerships and a faculty member at the World Trade Institute, in Bern, Switzerland, and a Visiting Professor at the College of Europe in Bruges.

\section{FNDNF}




\title{
A Plurilateral Agenda for Services? \\ Assessing the case for a Trade in Services Agreement (TISA)
}

\author{
Pierre Sauvé ${ }^{1}$
}

\section{Introduction}

On 15 February 2013, the European Commission formally proposed (in a submission to the European Council) to open negotiations on a new international agreement on trade in services. Initially called the "International Services Agreement" (ISA), the proposed plurilateral treaty currently involves a self-selected coalition of 22 WTO Members belonging to the so-called "Really Good Friends of Services" (RGFS) grouping. ${ }^{2}$ It has since been renamed the "Trade in Services Agreement" (TISA). The RGFS aim for the agreement to comply with WTO rules so it can be "multilateralized" at a later stage. ${ }^{3}$ Box 1 below reproduces in full the February 15 press communiqué released by the European Commission as it offers useful insights on the key policy motivations behind the initiative and the Commission's stated aims and expectations heading into the negotiations. ${ }^{4}$ The Commission's initiative comes on the heels of a similar process launched a few weeks earlier by the Obama administration in the United States. ${ }^{5}$

\section{Box 1. The EU seeks a mandate to enter into a plurilateral agreement on trade in services}

\section{The origins of the initiative}

To overcome the stalemate in the Doha negotiations (DDA), at the 8th Ministerial Conference of the WTO in December 2011, WTO Ministers acknowledged the impasse and made a commitment go ahead with negotiations in certain areas covered by the Doha negotiations with the aim of reaching "provisional or definitive agreements based on consensus earlier than the full conclusion of the single undertaking."

\footnotetext{
${ }^{1}$ The author is the Director of External Programs and Academic Partnerships and a faculty member at the World Trade Institute, in Bern, Switzerland, and a Visiting Professor at the College of Europe in Bruges. A preliminary version of this paper was presented at the European Parliament's Committee on International Trade on March 26, 2013. The author is grateful for discussions with and comments from Sherry Stephenson, Jane Drake-Brockman, Rudolf Adlung, Stephen Woolcock, Guy de Jonquières, Malcolm Bosworth, Gary Hufbauer, Bernard Hoekman, Crawford Falconer and Pasquale de Micco. E-mail: pierre.sauve@wti.org.

2 The RGFS grouping currently involved in the TISA talks includes the following WTO Members: Australia, Canada, Chile, Chinese Taipei, Colombia, Costa Rica, the European Union, Hong Kong, Iceland, Israel, Japan, Mexico, New Zealand, Norway, Pakistan, Panama, Paraguay, Peru, South Korea, Switzerland, Turkey and the United States.

${ }^{3}$ See Hufbauer, Jensen and Stephenson for an early depiction of the pluriateral agreement's main aims.

${ }^{4}$ See European Commission (2013).

${ }^{5}$ See World Trade Report (2013).
} 
In that spirit, WTO members went ahead with negotiations on trade facilitation and certain other areas. Some WTO members - originally led by the United States and Australia started floating the idea of a stand-alone agreement on trade in services to advance the DDA negotiations amongst willing WTO members.

\section{The participants}

The participants in this initiative are the so-called "Really Good Friends of Services". This "Really Good Friends" group is neither an exclusive nor a stable group of WTO members, but an ad-hoc coalition of all those WTO members that have shown a willingness to advance the services negotiations in the DDA. Countries involved in the plurilateral talks are a mix of developed and developing countries whose aggregate share of global trade in cross-border services (excluding intra-EU trade) stood at around two-thirds in 2010.

The EU would welcome any WTO members which share the objectives of the agreement to join the negotiations at any time.

\section{Main elements of the future agreement}

As an outcome of the exploratory talks that took place in 2012, the "Really Good Friends" agreed that any agreement would not simply be a Free Trade Agreement among the participants but would have the objective of being a full part of the WTO system.

1. The objective of the plurilateral trade in services agreement should be to negotiate an ambitious agreement that is compatible with the General Agreement on Trade in Services, (GATS), which would attract broad participation and which could be multilateralized at a later stage. Indeed, by staying close to the GATS, it could be easier to convince some of the leading emerging countries that were active in the DDA negotiations to join the initiative, either during the negotiations or later on.

2. The agreement should be comprehensive in scope with no exclusion of services sectors or modes of supply at the outset. Commitments taken by "Really Good Friends" should reflect the reality on the ground, i.e. the actual level of existing liberalization, and provide for new or improved market access.

All services sectors will potentially be covered by the negotiations, to the same extent they were covered by the GATS/DDA negotiations. However, it will be up to each participant to decide for which sector and to what extent it allows foreign services suppliers to provide services in their territory. The agreement will also include regulatory disciplines e.g. in the area of telecommunications, financial services or postal and courier services. These disciplines typically cover issues such as the independence of regulators, fair authorization processes or non-discriminatory access to telecommunication networks.

3. There should also be new and better rules on the basis of proposals brought forward by the participants. Members of the "Really Good Friends" made suggestions to include new rules, covering domestic regulation (e.g. authorization and licensing procedures), international maritime transport, telecommunication services, e-commerce, computer related services, cross-border data transfers, postal and courier services, financial services, temporary movement of natural persons, government procurement of services, export subsidies and state-owned enterprises. This list is based on the interests expressed by individual participants in the "Really Good Friends" group. It is not exhaustive and it does not mean it was agreed that there will be new or better rules in all the sectors listed. 


\section{Structure}

1. In terms of the structure of the agreement, it was agreed that it would be based on the GATS, with some core GATS articles (including on definitions, scope, market access and national treatment, general and security exemptions) being incorporated. This would, by and large, make it possible at a later stage to integrate the plurilateral agreement into the GATS.

2. There would be additional provisions to govern how each member of the "Really Good Friends" could take commitments. In this respect, it was agreed that commitments on national treatment would in principle be applied on a horizontal basis to all services sectors and modes of supply, i.e. the understanding on national treatment would be closer to the GATT model. Exemptions to this horizontal application would have to be listed in the countries' national schedule of commitments. Participants in the negotiations might also agree that commitments would in principle reflect actual practice (the "standstill clause") and that future elimination of discriminatory measures would be automatically locked in (the so-called "ratchet clause") unless an exemption were listed.

\section{Multilateralization: bringing the agreement under the WTO umbrella}

In a first phase, the agreement will only be binding upon the participants - and therefore will not be part of the DDA as such. But the EU has ensured that the structure of the agreement provides for a credible pathway to future multilateralization.

Two conditions are necessary for bringing the future agreement into the WTO system.

First, the type of obligations undertaken under the agreement need to be the same sort as in the GATS so they can be easily brought into the remits of the GATS. This will be ensured by relying on the same basic concepts (market access, national treatment...).

Second, the number of participants will need to reach a critical mass so that the benefits of the agreement can be extended to all WTO members.

In order to avoid free-riding, the automatic multilateralization of the agreement based on the Most Favored Nation (MFN) principle should be temporarily suspended as long as there is no critical mass of WTO members joining the agreement. At the same time, "Really Good Friends" agreed to include an accession clause for interested WTO members and a pathway to the multilateralization of the agreement, i.e. the agreement should set out the mechanisms and conditions for subsequent multilateralization.

\section{Next steps}

The negotiations are expected to start in spring 2013, once all participants have got their negotiating mandates. The negotiations will take place in Geneva.

Source: European Commission (2013).

This paper advances a set of conflicting thoughts on the proposed TISA. Bruised veterans of services trade negotiations, including the author of these lines, are logically prone to applauding the sight of forward movement in an area of trade governance whose potential 
for growth and development, as a source of vibrant export growth and as a means of durably facilitating the entry of firms, big and small, into global value chains, mercifully no longer require much convincing. It was not always thus! This is so even as the full potential of services trade remains fiendishly difficult to harness in a negotiating setting, and particularly so at the multilateral level.

Still, based on the limited information that has filtered on the TISA negotiations to date ${ }^{6}$, one may harbor a number of genuine doubts on the journey proposed, it's likely valueadded and the potentially damaging collateral effects it could yet exert on the WTO's ongoing services negotiations under the General Agreement on Trade in Services (GATS) and, more broadly, on the centrality of the WTO as a locus of trade governance. Simply put: if TISA holds considerable promise as a potentially innovative preferential services trade agreement pursued under the aegis of Article $V$ (Economic Integration) of the GATS, prospects of its eventual incorporation into the WTO architecture seem significantly less compelling for reasons, both procedural and substantive, that this note aims to explore.

\section{Recalling the starting point}

As the GATS approaches its twentieth birthday, it bears recalling that it remains to this day the sole piece of the Uruguay Round jigsaw that has yet to be solved, with leftover negotiations pending in core areas of services rule-making such as subsidy or procurement disciplines, non-discriminatory regulatory conduct or emergency safeguard measures.

That the Uruguay Round is not yet completed in services even as the Doha Round languishes in the twelfth year of its own tortured journey says a lot both about the inherent complexity of services rule-making and the difficulty of harnessing the forces of reciprocity in markets subject to a dense layer of domestic regulation, the political economy of which is often dauntingly intractable.

The Uruguay Round's negotiating harvest in services was a mere (and meek) down payment, richer on rules (even if incomplete) than on market opening commitments. The GATS was and remains the product of a first encounter towards which protagonists displayed the natural collective caution typically associated with novel endeavors. Confronted with what was largely a blank page - a frightening site for any policy official - early GATS negotiators had little choice but to tread lightly in what was essentially uncharted negotiating or rulemaking terrain.

Yet, in a world that has witnessed a highly service-centric technological revolution of unprecedented magnitude since the curtain fell on the Uruguay Round, one can readily appreciate the unease that flows, most palpably in corporate circles, from playing services

\footnotetext{
${ }^{6}$ A proxy of the (inadequate) level of transparency of the proposed plurilateral negotiations can be derived from the paucity of information on TISA yielded from a simple "Googling" of the proposed agreement's acronym.
} 
with yesterday's rule-book. That is, with the weak, incomplete, rules and the limited, regulatory precaution-laden, pre-internet, commitments of 1994.

In seeking the right epithet to characterize two and half decades' worth of efforts at prying open services markets, frustration probably ranks among the most apposite. The very currency of services negotiations consisting of domestic regulatory measures, dismantling the trade- and investment-impeding measures that lie chiefly behind borders implies that services talks are wholly akin to negotiations on non-tariff barriers. This is of essence a slow, ponderous, process. Proof of the above can be seen from the relative ease with which WTO members completed the 1996 International Technology Agreement ITA), a critical mass, MFN-based, tariff dismantling sectoral deal, with the continued difficulties and definitional quagmires they have subsequently confronted in trying to dismantle the broad range of nontariff measures inhibiting cross-border trade in IT products.

Meanwhile, those areas of services trade where the border retains crucial salience transport and labor movement for instance - are precisely the ones where market opening gains have been least impressive, including in the generally more liberalization-friendly confines of preferential trade agreements (PTAs).

Frustration over the glacial pace of multilateral market opening and over the inability of services to gain adequate traction in the DDA equation alongside agriculture and NAMA has prompted a large and growing number of WTO members to turn to PTAs as the chief vehicle to advance their services agendas and harvest the proceeds of far-reaching unilateral liberalization. To date, 108 such agreements have been notified to the WTO, a number of which have achieved significant WTO+ and WTO-X advances in the services field. ${ }^{7}$ TISA looks set to become the latest, and most important, such agreement.

\section{Plurilateral or preferential?}

A first question to raise in regard to TISA concerns its constitutional DNA. A negotiating process currently associating a coalition of 22 willing WTO Members (counting the EU-27 as one), TISA is unquestionably plurilateral in character. But it is plurilateral in the sense of the North American Free Trade Agreement (NAFTA) or of the Association of South-East Asian Nations' ASEAN Framework Agreement on Services (AFAS), not in that of the WTOembedded Government Procurement Agreement (GPA). This, as it happens, is a non-trivial distinction.

The above distinction matters to the extent that TISA proponents have repeatedly affirmed the hope of seeing the Agreement's subsequent multilateralization or, alternatively, its

\footnotetext{
${ }^{7}$ The terms WTO+ and WTO-X were first coined by Horn, Mavroidis and Sapir (2008) and refer to rules or market access commitments that go further than or involve a qualitative deepening over existing WTO rules or commitments (WTO+) or represent novel advances not yet found in the WTO (WTO-X).
} 
anchoring in the WTO in the manner of the GPA. Yet the fact that the negotiations currently proceed:

(i) without the formal ascent of the broader WTO membership;

(ii) in Geneva but wholly outside the WTO's perimeter;

(iii) at arm's length of the WTO secretariat (despite the professed desire of TISA protagonists to see the WTO become the Agreement's ultimate custodian);

(iv) among the RGFS grouping but without currently allowing for third country (and WTO Secretariat) observership (i.e. as a closed club),

are all suggestive of a potentially difficult migratory journey.

Rather than opening the TISA doors wide and large and afford all WTO members an opportunity to sit in and observe the negotiations in a transparent manner, determine where their interests lie in the deal on offer, allow those expressing a readiness to join (i.e. to move beyond mere observership towards active participation) the negotiations to contribute to shaping the Agreement's substantive texture and ultimately decide whether to opt-in or opt-out of the negotiated outcome, the TISA has to date operated as a closed club. That being the case, the recent history of trade multilateralism is strongly suggestive that this could be a major handicap from the perspective of any future WTO anchoring.

Indeed, for those old enough to have an institutional memory in these matters, such a process recalls the stillborn "Fu-Lung" Group, the name of the Chinese restaurant in Geneva where secretive discussions on financial services among G-10 central bankers and finance ministries (comprising the G-7 nations as well as Australia, the Netherlands and Switzerland) took place in the Uruguay Round's early days and which eventually led to the drafting of the Understanding on Commitments in Financial Services to which not a single non-OECD country signed onto by the Round's end.

The club mindset of TISA also recalls the failed quest for a "state of the art" Multilateral Agreement on Investment pursued in the mid-1990's at the Organization for Economic Cooperation and Development (OECD), yet another "us against them/build it and they'll beg to join" construct whose all too predictable failure contributed in no small measure to the WTO's subsequent inability to complete its own legislative arsenal by embedding a comprehensive set of investment rules under the so-called "Singapore Issues" agenda. More recently still, the failure of $A C T A^{8}$ in the area of intellectual property enforcement shared a number of procedural similarities with TISA.

The longer the TISA negotiating process retains its current closed shop mindset, the lesser will be the agreement's perceived multilateral legitimacy and the dimmer its prospects for

\footnotetext{
${ }^{8}$ ACTA is the acronym for Anti-Counterfeiting Trade Agreement, which aimed unsuccessfully to establish an international legal framework for targeting counterfeit goods, generic medicines and copyright infringement on the Internet. It would have created a new governing body outside existing intellectual property forums, such as the WIPO, the WTO or the UN. The Agreement's fate was sealed when the European Parliament voted overwhelmingly against its provisions in July 2012.
} 
later WTO anchoring. Such procedural opaqueness paradoxically affords key reluctant players - chief among which the leading emerging nations (the so-called BRIC nations of Brazil, India, Russia and China) or several important ASEAN Member States, none of whom are currently sitting at the TISA table - with a ready-made excuse to justify their nonparticipation in talks where genuine openness might help dampen conspiratorial instincts and prompt much needed pro-active engagement on their part.

Things look distinctively different if one looks at TISA as a WTO-sanctioned construct. At the end of the day, the most probable outcome will be to see TISA emerge as a preferential agreement on services proceeding on the basis of GATS Article V. Under WTO rules, WTO Members enjoy full rights to engage in PTA negotiations in services with the partner of their choice. Any such agreement need not raise any legitimacy concerns so long as it respects the legal strictures for WTO compatibility enounced in GATS Article V, the provisions of which are reproduced in Annex 1.

\section{When is a critical mass critical?}

A second major interrogation regarding the professed desire of the RGFS to see TISA multilateralized concerns the share of world commercial services trade the agreement could potentially cover. As Table 1 below reveals, the 22 countries currently party to the talks accounted for a combined 68.2 percent of world services trade in $2012 .{ }^{9}$ Fully 91 percent of this total relates to the services trade of TISA participating countries from the OECD area, with the 7 non-OECD countries associated to the talks providing the remaining 9 percent of covered trade. Hong Kong (China) and Chinese Taipei account together for close to ninetenths (87 percent) of the non-OECD country share, with no other developing country RGFS accounting for more than 0.3 of world exports of commercial services.

It remains an open question whether the above numbers amount to a credible critical mass, an issue that once more does not arise in the context of an Article $\mathrm{V}$ services PTA. By comparison, the three critical mass agreements concluded in the WTO to date - the 1996 Information Technology Agreement, the Agreement on Basic Telecommunications and the Financial Services Agreement, both of which were completed in 1997 - were all reached with coverage ratios exceeding $90 \%$ of total trade in the respective sectors or issue areas at play (see Box 2 below).

\section{Box 2. Negotiating on the basis of a critical mass approach}

The "critical mass" approach involves negotiations between a number of parties that do not represent the entire membership but nonetheless conduct a very high proportion of

\footnotetext{
${ }^{9}$ All figures are from the World Trade Organization's International Trade Statistics 2012 report available at http://www.wto.org/english/res e/statis e/its2012 e/its12 toc e.htm
} 
international trade in a particular good or service and agree upon a common course of action to be taken under the auspices of the WTO. ${ }^{10}$

In the area of trade in goods, a critical mass approach was used when negotiating the Information Technology Agreement ("ITA"). The ITA was a Ministerial Declaration signed in 1996 by 29 WTO Members, who agreed to cut and bind tariffs on information technology products covered by the Declaration to zero and to bind all other duties and charges for these products also at zero. The ITA did not foresee an exception to the MFN obligation and the benefits of the Declaration were extended to all WTO Members on an unconditional MFN basis.

To address the problem of "free riding" by other WTO Members that did not agree to cut their tariffs and other duties and charges according to the ITA, it was agreed that all Members accounting for a significant share of trade in information technology products would need to participate. The ITA provided that it would only enter into force when the participants that notified their acceptance of the Agreement would represent approximately 90 per cent of world trade in information technology products. This threshold was met in July 1997, when the ITA entered into force.

Negotiations in services conducted under the auspices of the General Agreement on Trade in Services (GATS) have also made use of a critical mass approach during the Uruguay Round. In telecommunications and financial services, a subset of WTO Members negotiated commitments that went beyond what was included in the GATS. However, the benefits of both such agreements were extended on an MFN basis. ${ }^{11}$

With regard to financial services, an Understanding on Commitments in Financial Services was negotiated during the Uruguay Round. Negotiations in the financial sector continued after the end of the Round and further commitments were made in two Protocols that only entered into force when a "critical mass" of WTO Members participated. In basic telecommunication services, a number of Members felt during the Uruguay Round that effective market access for telecommunication service suppliers could be undermined through governmental measures not regulated by the GATS. Therefore, common regulatory principles and pro-competitive disciplines were developed in the Negotiating Group on Basic Telecommunications and laid down in a Reference Paper on Basic Telecommunications. A Protocol ensured that the Reference Paper would not enter into force (in this case, by including a version of the Reference Paper as "additional commitments" in Members' schedules of commitments (typically under the "Additional Commitments (Article XVIII) column) before a "critical mass" of WTO Members participated. Such additional commitments were also extended on an unconditional MFN basis.

Source: Harbinson and De Meester (2012).

\footnotetext{
${ }^{10}$ This is not currently the case of TISA, whose negotiations, as noted above, do not associate the WTO Secretariat nor proceed under the WTO's auspices.

${ }^{11}$ If a subset of WTO Members wished to conclude agreements whose benefits are not extended to all WTO Members, they would need to conclude preferential trade agreements that comply with the conditions laid down in Article $V$ of the GATS or conclude recognition agreements that comply with the conditions set out in Article VII of the GATS.
} 
The perception, largely corroborated by Table 1 data, that TISA, as currently configured, is chiefly an agreement for and by advanced industrialized nations, once again raises doubts over the smoothness of its possible subsequent multilateralization.

Table 1. Share of TISA participants in world services trade

\begin{tabular}{|c|c|}
\hline TISA Participant & $\begin{array}{c}\text { Share of World Services } \\
\text { Trade (\%) }\end{array}$ \\
\hline Australia & 2.4 \\
\hline Canada & 3.5 \\
\hline Chile & 0.6 \\
\hline Chinese Taipei & 2.1 \\
\hline Colombia & 0.2 \\
\hline Costa Rica & 0.2 \\
\hline European Union & 36.4 \\
\hline Hong Kong, China & 5.6 \\
\hline Iceland & 0.1 \\
\hline Israel & 1.2 \\
\hline Japan & 6.6 \\
\hline Korea & 4.3 \\
\hline Mexico & 0.7 \\
\hline New Zealand & 0.5 \\
\hline Norway & 1.9 \\
\hline Pakistan & 0.2 \\
\hline Panama & 0.3 \\
\hline Paraguay & 0.1 \\
\hline Peru & 0.2 \\
\hline Switzerland & 4.4 \\
\hline Turkey & 1.8 \\
\hline United States of America & 26.9 \\
\hline Share of world total & 68.2 \\
\hline $\begin{array}{l}\text { Of which: Share of OECD } \\
\text { country TISA participants }\end{array}$ & 91.0 \\
\hline $\begin{array}{c}\text { Share of non-OECD country } \\
\text { TISA participants }\end{array}$ & 9.0 \\
\hline
\end{tabular}

Source: WTO (2013).

\section{Beware of architectural dissonance}


The universe of agreements on trade in services is today almost equally divided between agreements that follow the negotiating modalities of the GATS, which are predicated on a hybrid approach ${ }^{12}$ to scheduling commitments across 4 distinct modes of service supply and those, slightly more numerous today and which, following the 1994 North American Free Trade Agreement (NAFTA), turned the GATS upside down in pursuing a negative list approach to market opening. In the latter agreements, commitments relate to the preservation, in so-called "reservation lists", of existing non-conforming (i.e. treaty inconsistent) measures or the identification (in a separate reservation list) of sectors where scope for the introduction of future non-conforming measures can be maintained (the negative list equivalent of an "unbound" sectoral commitment in GATS-like agreements).

Significant experimentation in approaches to market opening has been pursued in recent years in the proliferating set of services PTAs, with combined approaches increasingly common - for instance a negative list approach for investment in services and a positive list approach for cross-border trade or other such variations. ${ }^{13}$

Despite the professed desire of TISA participants to craft an agreement that is compatible with the GATS so as to facilitate its eventual multilateralization, the TISA appears to be clearly departing from GATS practice by proposing to liberalize national treatmentinconsistent measures via a negative list approach while maintaining a positive list approach for market access commitments. The likely rationale behind such segmentation could well lie in the fact that governments often find it easier to progressively liberalize discriminatory domestic regulations, which typically nonetheless allow for some (constrained) market contestability, than to dismantle quantitative restrictions limiting competition in services markets. The political economy of dismantling quota rents is indeed often more challenging given the political influence of those who hold such rents.

The adoption of such a novel approach to market opening would once more be perfectly feasible and uncontroversial in the context of an Article $V$ agreement given the prevalence of PTA precedence. Its adoption in an agreement slated for subsequent multilateralization would, however, likely give rise to complex problems of legal co-existence and interpretation with regard to existing GATS commitments. This is so to the extent that, as currently holds, a large number of GATS provisions only apply if and when a specific commitment (on national treatment and market access) is scheduled.

Under TISA's proposed segmented approach to scheduling, a number of GATS disciplines for instance on payments and transfers - would automatically apply to all measures affecting trade and investment in services that are left off the negative list of national treatmentinconsistent measures but would only be applicable in sectors and modes of supply where positively listed market access commitments were scheduled. Such dualist treatment would

\footnotetext{
${ }^{12}$ The hybrid approach to scheduling commitments under the GATS involves the positive choice of sectors, subsectors and modes of supply which WTO members voluntarily choose to place in their schedules combined with the negative listing of limitations maintained in scheduled sectors, sub-sectors or modes of supply.

${ }^{13}$ For a fuller discussion of differing negotiating architectures in PTAs, see Mattoo and Sauvé (2011).
} 
appear devoid of any sensible policy rationale, all the more so when one considers that the frequency of quantitative restrictions to services trade is typically greater than that of discriminatory measures.

Questions also arise as to the means under TISA to procure future regulatory immunity in respect of discriminatory measures, as the negative list approach to national treatment would solely lock in measures at their existing level of non-conformity and oblige signatories to accept that all future measures in the same sector or, more controversially still, in new (i.e. future) sectors be automatically bound at free. Such an outcome would of essence require that TISA replicate provisions, common to all negative list PTAs, allowing scope for Parties to preserve the right to introduce new non-conforming measures in sectors with acute policy sensitivities. For the European Union, this would be the only means of accepting that TISA covers trade in sectors such as audio-visual, education or health services as the EU could then reserve such entire sectors from the Agreement's scope of coverage. The main policy lesson to be derived from the above discussion is a relatively simple one: the greater the architectural dissonance between TISA and the GATS, the harder the eventual normative migration to the WTO could prove to be.

Rather than pursue an approach to liberalization sure to sow greater confusion and give rise to heightened legal complexity (a likely major private sector turn-off), TISA proponents should rather consider forward-looking ways of remedying a number of the foundational weaknesses of the GATS in regard to scheduling commitments ${ }^{14}$ by adopting practices that have been successfully pursued in a number of more recent PTAs, including by the EU in its Economic Partnership Agreement with CARIFORUM Member States. ${ }^{15}$

Were TISA participants genuinely concerned by TISA's subsequent multilateralization, the RGFS could seek to replicate the voluntary, bottom-up, approach to scheduling commitments of the GATS but condition such an approach on two important qualitative improvements:

(i) the adoption of a new provision mandating that any commitment voluntarily scheduled lock in the regulatory status quo (i.e. that TISA signatories no longer bind less than the access flowing from prevailing regulatory regimes); and

(ii) the incorporation into TISA of country-specific annexes featuring non-binding negative lists of non-conforming measures, documenting, solely for

\footnotetext{
${ }^{14}$ Arguably the greatest weakness of the GATS (and of PTAs predicated on the GATS approach) in respect of its market opening provisions is the fact that the Agreement allows Parties to schedule commitments below the regulatory status quo, i.e. to maintain a gap between existing (applied) regulations and what appears in their GATS schedules. This in effect replicates the gap found under GATT between bound and applied tariffs in WTO Members' tariff schedules.

${ }^{15}$ For a fuller discussion of the substantive provisions on services found in the EU-CARIFORUM Economic Partnership Agreement, see Sauvé and Ward (2009).
} 
transparency promoting purposes, all treaty inconsistent measures maintained by Parties.

Such a dual approach would largely approximate the good governance and transparency promoting properties of negative listing and ensure that TISA commitments relate to specific, existing, measures and no longer merely to a GATS-like standard of treatment that may be divorced from prevailing regulatory realities. The production of non-binding negative lists would allow members to conduct useful domestic audits of the optimality of their services regimes while also generating information that could usefully allow for a rankordering of measures based on their commercial and negotiating importance. Such an approach would thus generate information of considerable use to policy officials conducting periodic rounds of negotiations, allowing them to devise formula-based approaches to market opening in areas or sectors where the nature and incidence of policy restrictions appears convergent. The transparency gains flowing from such an approach would also yield commercially useful information for private sector users, who would be supplied a full mapping of regulatory restrictions likely to be encountered in foreign markets.

A further, if potentially more controversial, element to ponder in TISA's market opening arsenal could be the adoption of a so-called "ratchet clause", found today in a large number of PTAs (particularly in the Western Hemisphere) and through which unilateral liberalization measures enacted between negotiating rounds would automatically be bound at the new level of (lessened) non-conformity under TISA.

\section{The fate of sensitive sectors and modes of supply}

Everybody has ghosts in its closet. For the United States, the maritime sector has historically proven impervious to services trade talks, followed more recently by Mode 4 trade (arguably in violation of Article $V$, which states that services PTAs should not exclude any mode of supply on an a priori basis ${ }^{16}$. For the EU and Canada, audio-visual services remain no-go zones in services trade, as are publicly-funded health and education services in a large number of countries taking part in TISA talks.

Trade in air transport services offers another example of a sector largely immune from the forces of trade negotiating-induced liberalization. This is so despite the globally competitive nature of the industry, the continued need for airline consolidation and the lower cost of capital that a progressive lifting of onerous ownership restrictions would entail, as well as its central importance as a means of ferrying both goods and people (business people and tourists) to market.

\footnotetext{
${ }^{16}$ No PTA concluded by the United States since its bilateral agreement with Australia in 2004 has featured negotiated commitments on the temporary entry of service providers.
} 
The question naturally arises of those sectors in which TISA could generate the value-adding WTO+ and WTO-X commitments expected of its chief protagonists. A related question is the likelihood that TISA's political economy, particularly in the absence of large developing countries such as China, Brazil, India, Indonesia, South Africa or any number of leading ASEAN Member States, will be conducive to putting on the table what has largely stayed off it so far at the WTO and in many PTAs.

There are generally few signs suggesting a major shift in US attitudes towards maritime transport or Mode 4 liberalization ${ }^{17}$, nor would much hope appear warranted in the sudden ability of the EU or Canada to drop their long-standing reluctance to revisiting the case for market opening in audio-visual or other services with notable public good characteristics. The above questions are equally germane in regard to the probable liberalization harvest of the proposed Transatlantic Trade and Investment Partnership (TTIP). Still, the TISA offers a platform for its participants to try as best they can to push the liberalization envelope in new directions, where the scope for binding commitments may have newly opened up as a result of recent autonomous liberalization, changes in market structures or novel advances in procompetitive regulation. Sectors that come most prominently to mind in this regard include a wide range of environmental services, energy-related services as well as postal and courier services.

One area where TISA could usefully break new ground would be in testing out novel formula-based approaches to market opening, devising deeper à la carte liberalization packages using model schedules, collective requests to remove selected modal or sectorspecific impediments such as foreign equity limitations or economic needs tests linked to licensing, as well as multi-sectoral clustering - for instance a TISA cluster on trade facilitation services combining transportation, distribution, customs brokerages and associated border management consulting services, warehousing, express delivery and logistics services. Another cluster where forward movement should be conceivable would relate to a package of IT-related business services (including selected professions with accompanying Mode 4), particularly in regard to Mode 1 trade, which could be packaged as the services complement to the WTO's Information Technology Agreement.

Should TISA delve more deeply into new sectors, notably those with network properties, such as waste disposal services, water and energy distribution or rail transportation, participating countries should explore the scope for developing new sets of pro-competitive regulatory disciplines first pioneered in the Uruguay Round's overtime talks on basic telecommunications.

Finally, there would seem every reason for TISA to take stock of the post-Uruguay Round revolution in digital trade and codify the latest set of trade-facilitating, pro-competitive, and

\footnotetext{
${ }^{17}$ It remains to be seen how the recent terrorist attack in Boston will, alongside continued concerns over white collar outsourcing, impact ongoing discussions on immigration and temporary work permit reforms in the United States.
} 
net neutral disciplines aimed at preserving transactional freedoms in cyberspace. This is a terrain that has already been mined extensively in chapters on digital trade in the PTAs of many TISA participants. Such precedents should, once again, facilitate TISA codification. However, in tackling the digital trade agenda, one should not underestimate the scope of a possible transatlantic divide on issues linked to data privacy and IP protection, both of which are salient in discussions of new disciplines on cross-border data flows.

\section{TISA as a rule-making laboratory?}

The unfinished rule-making agenda of the GATS is by no means a multilateral monopoly. By and large, such an agenda has yet to be tackled meaningfully at the level of PTAs, with the notable, and commercially important, exception of government procurement in services.

Still, to the extent that a very large number of TISA participants have concluded PTAs in services with each other (see Table 2 below), significant (though by no means full) procurement liberalization in services has already been achieved. TISA offers scope for deepening this process, notably at the sub-federal level, but here again one needs to ponder the incentive for the US, Canada, Japan, Australia or any large individual EU member with a federal political structure to open up this politically sensitive sector in return for reciprocal access to markets that are distinctly smaller in size and where market opening talks have already proceeded in most instances. Indeed, the issue of services procurement already is or will soon be at the core of ongoing bilateral negotiations between key TISA partners, notably the EU, Canada, the US, Australia and Japan (including under the TPP and the TTIP).

PTAs to date have shown a limited capacity to make headway beyond procurement on the unfinished agenda of the GATS. This reflects a clear (and recurring) revealed preference for regulatory inaction on issues such as subsidy disciplines or emergency safeguard measures, where many TISA participants remain deeply skeptical, including on feasibility grounds.

Some progress could however be expected on the issue of non-discriminatory domestic regulation, but more along the lines of DDA discussions on greater transparency than in the direction of the development of a full-blown necessity test for services.

The reluctance of large players such as the US, Canada and the EU to do for services what they have long done for goods trade under TBT and SPS disciplines remains paradoxical, all the more so as the US and the EU, as the world's leading exporters of services, remain the most likely victims of needlessly burdensome or disproportionate regulatory conduct in foreign markets. Doubts can legitimately be expressed as to whether TISA could meaningfully break the above rule-making logjam, a rare instance where the quest for regulatory immunity trumps industry interests.

Meanwhile, it begs recalling that that some of TISA's strongest protagonists seem to attach importance to regulatory transparency that is perhaps more rhetorical than real if one is to 
go by the number of services measures notified under Article III.3 of the GATS. Since 2000, the US, the EU, Canada and Australia have collectively notified 4 new measures affecting their GATS commitments, as opposed to 60 each for Switzerland and China and 120 for Albania! 
Table 2. Lots of Really Good Friends: Existing and Planned PTAs in Services among TISA Partners

\begin{tabular}{|c|c|c|}
\hline TISA Negotiating Partner & Existing Agreements with TISA Partners & Agreements Under Negotiation with TISA Partners \\
\hline Australia (AU) & 3 (CHL; NZ; US) & 4 (JP; KO; MX; PE) \\
\hline Canada (CA) & 5 (CHL; CO; MX; PE; US) & 6 (EU; IC; JP; KO; NO; CH) \\
\hline Chile (CHL) & $\begin{array}{l}16 \text { (AU; CA; CO; CR; EU; HK; IC; JP: KO; MX; NZ; NO; PAN; } \\
\mathrm{PE} ; \mathrm{CH} ; \mathrm{US})\end{array}$ & 0 \\
\hline Chinese Taipei (CHT) & 1 (PAN) & 0 \\
\hline Colombia (CO) & 9 (CA; CHL; EU; IC; MX; NO; PE; CH; US) & 0 \\
\hline Costa Rica (CR) & 6 (CH; EU; MEX; PAN; PE; USA) & 0 \\
\hline European Union (EU) & 9 (CHL; CO; CR; ICL; KOR; MEX; NOR; PAN; PE) & 4 (CA; ISL; JP;US) \\
\hline Hong Kong China (HK) & 5 (CHL; IC; NZ; NO; CH) & 0 \\
\hline Iceland (IC) & 8 (CHL; CO; EU; HK; KO; MX; NO; CH) & $1(\mathrm{CA})$ \\
\hline Israel (ISL) & 0 & $1(\mathrm{EU})$ \\
\hline Japan (JP) & 4 (CHL; MX; PE; CH) & 7 (AU; CA; CO; EU; KO ; NZ; US) \\
\hline Korea (KO) & 8 (CHL; $\mathrm{CO} ; \mathrm{EU} ; \mathrm{IC} ; \mathrm{NO} ; \mathrm{PE} ; \mathrm{CH} ; \mathrm{US})$ & 5 (AU; CA; JP; MX; NZ) \\
\hline Mexico (MX) & 10 (CHL; CO; CR; EU; IC; JP; NO; PE; CH; US) & $3(\mathrm{AU} ; \mathrm{KO} ; \mathrm{NZ})$ \\
\hline New Zealand (NZ) & $3(\mathrm{AU} ; \mathrm{CHL} ; \mathrm{HK})$ & 5 (JP; KO; MX; PE; US) \\
\hline Norway (NO) & 8 (CHL; CO; EU; HK; IC; KO; MX; CH) & $1(\mathrm{CA})$ \\
\hline Pakistan (PK) & 0 & 0 \\
\hline Panama (PAN) & 6 (CHL; CHT; CR; EU; PE; US) & 0 \\
\hline Paraguay (PAR) & 0 & 0 \\
\hline Peru (PE) & 10 (CA; CHL; CO; CR; EU; JP; KO; MX; PAN; US) & $2(\mathrm{AU} ; \mathrm{NZ})$ \\
\hline Switzerland $(\mathrm{CH})$ & 8 (CHL; CO; HKC; IC; JP; KO; MX; NO) & $1(\mathrm{CA})$ \\
\hline Turkey (TU) & 0 & 0 \\
\hline United States (US) & 9 (AU; CA; CHL; CO; CR; KO; MX; PAN; PE) & 3 (EU; JP; NZ) \\
\hline
\end{tabular}

Source: Author's calculations based on Marchetti and Roy (forthcoming). 


\section{Tentative conclusions}

It is possible to express genuine concerns about a negotiating process while still hoping it can garner useful forward looking traction. This is very much the predicament one faces in looking at TISA.

The substantive merits of a proposed TISA would be easy to applaud if it the negotiations were presented for what they truly are more clearly from the outset: as the potentially largest GATS Article V PTA in services concluded to date. Meanwhile, and based on the limited information that has filtered to date on the nascent plurilateral talks, a number of genuine reservations may be advanced, both procedural and substantive in nature, that the Agreement being devised could easily or anytime soon be incorporated into the WTO architecture and co-exist alongside the GATS (and least of all replace it). That there is no precedent for such coexistence in the GATT-WTO history should already be a cause for concern to TISA protagonists.

The world economy as a whole and every WTO member for that matter, regardless of income level, stand to gain from greater, more transparent and progressively more liberal trade and investment conditions in services markets. Services are central to all that an economy produces, exports, and invests in, such that an inefficient service sector represents a perverse tax on economy-wide efficiency. The growing acceptance of this central economic reality has fuelled unprecedented autonomous liberalization in services markets around the globe in recent decades. ${ }^{18}$ Trade agreements, and especially the GATS, have not yet proven adept at locking in such autonomous policy virtue. In the case of the GATS, broader negotiating dynamics in the Doha Round may well have exerted the largest inhibiting influence.

Progress in negotiated market opening in services markets has been significantly greater in PTAs to date, if far from complete and still uneven across sectors. Table 3 below documents the implicit preference margins that hold across service sectors. It does so by comparing the Uruguay Round commitments of WTO Members, their latest Doha Round offer as well as the most liberal treatment on offer in such members' latest PTAs. ${ }^{19}$

The advent of TISA represents a genuine opportunity to further advance the cause of preferential liberalization in services markets among a coalition of countries representing close to seven tenths of the global market. While this remains significantly less that which was achieved in recent plurilateral agreements brokered at the WTO, it is far from trivial in potential market access terms.

Moreover, the TISA talks have rekindled marked interest on the part of private operators and industry associations in championing negotiated market opening, recalling at times the

\footnotetext{
${ }^{18}$ See Schott and Muir (2012) and Ghani and Kharas (2010).

${ }^{19}$ For a fuller discussion, see Marchetti and Roy (2008), Mattoo and Sauvé (2011) and Sauvé and Shingal (2011).
} 
early feverish days of the Uruguay Round. ${ }^{20}$ Failure to respond to such renewed private sector engagement would represent an unfortunate missed opportunity. Yet, in pursuing TISA, greater attention needs to be paid to the negotiating atmospherics and concrete steps taken to promote far greater inclusiveness, including on the part of the WTO secretariat in an observer capacity, than has been the case so far.

Table 3. Implicit margins of preference in services trade: comparing the level of services trade liberalization across sectors

$\begin{array}{lcccccc}\text { Sectors } & \text { GATS } & \text { DDA Offers (o to 100) } & \text { PTAs } & \text { GATS/PTAs (\%) } & \text { DDA/PTAs (\%) } & \text { Preference Margin } \\ \text { Professional } & 30 & 39 & 67 & 45 & 58 & 42-55 \\ \text { Computer } & 55 & 74 & 93 & 59 & 80 & 20-41 \\ \text { Postal/Courrier } & 14 & 20 & 53 & 26 & 38 & 62-74 \\ \text { Telecoms } & 51 & 58 & 80 & 64 & 73 & 28-36 \\ \text { Audiovisual } & 17 & 20 & 50 & 34 & 40 & 60-66 \\ \text { Construction } & 40 & 46 & 75 & 53 & 61 & 39-47 \\ \text { Distribution } & 32 & 41 & 76 & 42 & 54 & 46-58 \\ \text { Education } & 18 & 25 & 57 & 32 & 44 & 56-68 \\ \text { Environmental } & 20 & 30 & 62 & 32 & 48 & 52-68 \\ \text { Financial } & 36 & 40 & 53 & 68 & 75 & 25-32 \\ \text { Health } & 8 & 11 & 34 & 24 & 32 & 68-76 \\ \text { Tourism } & 51 & 61 & 83 & 61 & 73 & 27-39 \\ \text { Maritime } & 12 & 23 & 57 & 21 & 40 & 60-79 \\ \text { Rail } & 14 & 20 & 52 & 27 & 38 & 62-73 \\ \text { Road } & 16 & 18 & 56 & 29 & 32 & 68-71 \\ \text { Aux. Transport } & 21 & 24 & 58 & 36 & 41 & 59-64\end{array}$

Source: Sauvé and Shingal (2011).

At a critical juncture for the WTO and the DDA, one may legitimately ponder the systemic implications of the proposed TISA and question the incentives its completion would entail for the DDA's services talks should agreement be reached among the RGFS grouping.

This paper has suggested a number of relatively simple corrective gestures that could be taken to ensure that the negotiating process is more genuinely inclusive and transparent and does not needlessly pit developing countries against the predominantly OECD-centric RGFS grouping in a manner that could prove inimical to the confidence, goodwill and cooperation that will need to be supplied in vastly greater quantities for the DDA to be completed and for

\footnotetext{
${ }^{20}$ See World Trade Report (2013).
} 
the WTO's credibility as a liberalizing legislature to be restored. TISA participants could furthermore adopt approaches to liberalization and rule-making with a view to facilitating, rather than hindering, the process of eventual anchoring in the WTO. This paper has advanced a few practical ideas to this end.

Looking ahead, plurilateralism and variable geometry approaches to rule-making and market opening are likely to prove important ways of keeping the WTO relevant, of sustaining the multilateral bicycle's forward journey while also acknowledging the increasing diversity of collective preferences - and concomitant interests and abilities- among a membership made up today overwhelmingly of developing countries whose primary export interests may not always lie in services (even as their infrastructural import needs should prompt greater engagement in services talks).

Whenever possible, WTO Members should explore and pursue, under one common roof, the scope that exists for flexible approaches to rule-making and market opening commanding adequate critical mass. Pursuing plurilateral outcomes in an open setting that allows for economies of scale and learning is not the same thing as negotiating behind closed doors. History has not been kind to the latter initiatives.

An important final question, not addressed in this paper but germane in the context of the ongoing discussion on a trade in services waiver for least developed countries (LDCS), is whether TISA outcomes should be extended automatically and unconditionally to LDCS on a non-reciprocal basis. 


\section{Annex 1. Article V of the GATS (Economic Integration)}

\section{Article $V$}

\section{Economic Integration}

1. This Agreement shall not prevent any of its Members from being a party to or entering into an agreement liberalizing trade in services between or among the parties to such an agreement, provided that such an agreement:

(a) has substantial sectoral coverage ${ }^{21}$, and

(b) provides for the absence or elimination of substantially all discrimination, in the sense of Article XVII, between or among the parties, in the sectors covered under subparagraph (a), through:

(i) elimination of existing discriminatory measures, and/or

(ii) prohibition of new or more discriminatory measures,

either at the entry into force of that agreement or on the basis of a reasonable time-frame, except for measures permitted under Articles XI, XII, XIV and XIV bis.

2. In evaluating whether the conditions under paragraph 1 (b) are met, consideration may be given to the relationship of the agreement to a wider process of economic integration or trade liberalization among the countries concerned.

3. (a) Where developing countries are parties to an agreement of the type referred to in paragraph 1, flexibility shall be provided for regarding the conditions set out in paragraph 1 , particularly with reference to subparagraph (b) thereof, in accordance with the level of development of the countries concerned, both overall and in individual sectors and subsectors.

(b) Notwithstanding paragraph 6, in the case of an agreement of the type referred to in paragraph 1 involving only developing countries, more favorable treatment may be granted to juridical persons owned or controlled by natural persons of the parties to such an agreement.

4. Any agreement referred to in paragraph 1 shall be designed to facilitate trade between the parties to the agreement and shall not in respect of any Member outside the agreement raise the overall level of barriers to trade in services within the respective sectors or subsectors compared to the level applicable prior to such an agreement.

\footnotetext{
${ }^{21}$ This condition is understood in terms of number of sectors, volume of trade affected and modes of supply. In order to meet this condition, agreements should not provide for the a priori exclusion of any mode of supply.
} 
5. If, in the conclusion, enlargement or any significant modification of any agreement under paragraph 1, a Member intends to withdraw or modify a specific commitment inconsistently with the terms and conditions set out in its Schedule, it shall provide at least 90 days advance notice of such modification or withdrawal and the procedure set forth in paragraphs 2, 3 and 4 of Article XXI shall apply.

6. A service supplier of any other Member that is a juridical person constituted under the laws of a party to an agreement referred to in paragraph 1 shall be entitled to treatment granted under such agreement, provided that it engages in substantive business operations in the territory of the parties to such agreement.

7. (a) Members which are parties to any agreement referred to in paragraph 1 shall promptly notify any such agreement and any enlargement or any significant modification of that agreement to the Council for Trade in Services. They shall also make available to the Council such relevant information as may be requested by it. The Council may establish a working party to examine such an agreement or enlargement or modification of that agreement and to report to the Council on its consistency with this Article.

(b) Members which are parties to any agreement referred to in paragraph 1 which is implemented on the basis of a time-frame shall report periodically to the Council for Trade in Services on its implementation. The Council may establish a working party to examine such reports if it deems such a working party necessary.

(c) Based on the reports of the working parties referred to in subparagraphs (a) and (b), the Council may make recommendations to the parties as it deems appropriate.

8. A Member which is a party to any agreement referred to in paragraph 1 may not seek compensation for trade benefits that may accrue to any other Member from such agreement. 


\section{References}

European Commission (2013), "Negotiations for a Plurilateral Agreement on Trade in Services", Europa Communiqués de Presse, Memo/13/107, Brussels: European Commission, (15 February 2013). Available at http://europa.eu/rapid/press-release MEMO-13-107 en.htm

Ghani, E. and H. Kharas (2010), "The Services Revolution”, Economic Premise, No. 14, Washington, D.C.: the World Bank. Available at http://siteresources.worldbank.org/INTPREMNET/Resources/EP14.pdf

Harbinson, Stuart and Bart de Meester (2012), A $21^{\text {st }}$ Century work program for the multilateral trading system, Washington, D.C.: National Foreign Trade Council. Available at http://www.nftc.org/default/trade/WTO/NFTC21stCenturyTradeAgenda2012.pdf Horn, H., P. Mavroidis and A. Sapir (2008), Beyond the WTO? An anatomy of EU and US preferential trade agreements, Bruegel Blueprint Series, Volume VII, Brussels: Bruegel.

Hufbauer, G. C., J. Bradford Jensen and S. Stephenson (2012), "Framework for the International Services Agreement", Policy Brief, Number 10-12, (April), Washington. D.C.: Peterson Institute for International Economics.

Marchetti, J. and M. Roy (2008), Opening Markets for Trade in Services: Countries and Sectors in Bilateral and WTO Negotiations, Cambridge: Cambridge University Press.

Marchetti, J. and M. Roy (forthcoming), "The TISA initiative: an overview of market access issues", WTO Discussion Paper, Geneva: World Trade Organization.

Mattoo, A. and P. Sauvé (2011), "Services", in Chauffour, J.-P. and J.-C. Maur, eds., Preferential Trade Agreement Policies for Development: A Handbook, Washington, D.C.: The World Bank, pp. 235-274.

Sauvé, P. and A. Shingal (2011), "Reflections on the Preferential Liberalization of Services Trade", in Journal of World Trade, Vol. 45, No. 5, pp. 953-63.

Sauvé, P. and N. Ward (2009), "The EC-CARIFORUM Economic Partnership Agreement: Assessing the Progress on Services and Investment, ECIPE Paper, Brussels: European Centre for International Political Economy, (January). Available at http://www.ecipe.org/publications/ecipe-working-papers/the-ec-cariform-economicpartnership-agreement-assessing-the-outcome-on-services-and-investment

Schott, J. and J. Muir (2012), "Prospects for Services Trade Negotiations", Peterson Institute for International Economics Working Paper 12-17 (October), Washington, D.C.: Peterson Institute for International Economics.

World Trade Organization (2013), International Trade Statistics 2012, Geneva: World trade Organization. Available online at:

http://www.wto.org/english/res e/statis e/its2012 e/its12 toc e.htm 
World Trade Report (2013), "USTR Receives Comments on Proposed International Services Agreement", Washington, D.C.: World Trade Report, Vol. 29, No. 8, (4 March). 